\title{
GAFATAR DAN DINAMIKA GERAKAN SOSIALNYA
}

\section{Enkin Asrawijaya}

\author{
Mahasiswa Program Doktoral Ilmu-ilmuHumaniora UGM dan Dosen di Sekolah \\ Tinggi Agama Islam Bakti Negara (STAIBN) Tegal, Jawa Tengah \\ Email : enkinasrawijaya@gmail.com
}

\begin{abstract}
Gafatar is a form of community upheaval in Indonesia in the current reform era. Issues surrounding the ideology and the attempts of treason case became the problem that caused Gafatar to lose the masses of the public. Gafatar has the concept of food self-sufficiency which is then implemented in a peasant movement as its criticism of the government. To explain the dynamics of the Gafatar social movement, used the theory of McAdam et al, about Political Opportunities, Mobilizing Structures, and Cultural Framings. The political opportunity arises from the distrust of government programs that have been offered to the people who are deemed to be ineffective. Mobilizing Structur Gafatar movement is manifested through the formation of the organization, forming a network of cooperation and collective action. While cultural framing, created through the issues addressed to Gafatar causing the formation of negative stigma in society.
\end{abstract}

Keywords: Gafatar, Social Movement, and Community

\section{PENDAHULUAN}

Tulisan ini tidak bermaksud untuk mengungkit luka lama, dan juga tidak untuk menghakimi sebuah organisasi beserta ideologinya yang dipandang sesat oleh pemerintah maupun sebagian masyarakat. Uniknya fenomena ini karena mereka menggunakan konsep swasembada pangan yang kemudian diimplementasikan dalam sebuah gerakan petani sebagai kritiknya terhadap pemerintah.

Kajian tentang Gafatar sejauh ini belum banyak yang membahas, padahal studi seperti ini sangat penting terkait dengan gerakan sosial yang pernah ada di Indonesia, terutama di era postmodern seperti sekarang ini sehingga menambah khasanah ilmuilmu sosial humaniora.

Kasus Gafatar (Gerakan Fajar Nusantara) mencuat pada November 2016, ketika terjadi pembakaran di perkampungan kelompok tani Gafatar di Mempawah Timur, Kalimantan Barat ${ }^{1}$. Gafatar merupakan sebuah organisasi yang lahir di tahun 2011 dan di vonis sesat sejak 2016 oleh pemerintah Indonesia. Isu-isu seputar ideologi, upaya makar dan kasus penculikan menjadi permasalahan yang menyebabkan Gafatar kehilangan massa publik sehingga terjadi deligitimasi.

1Fira "Pengusiran 1.000 Eks Anggota Gafatar Merupakan Pelanggaran", Diakses dari http://www.obsession news.com/daerah/pengusiran-1-000-eks-anggota-gafatar-merupakanpelanggaran/, pada tanggal21 Januari 2016pukul 10.16 
Gafatar merupakan bentuk dari pergolakan masyarakat di Indonesia pada era reformasi saat ini, namun memiliki durasi yang singkat. Bentuk perlawanan yang dilakukan tidak melalui pemberontakan dan kekerasan melainkan dilakukan melalui beberapa program-program kedaulatan pangan yang mereka buat sebagai langkah dan strategi dalam melakukan perlawanan terhadap hegemoni penguasa.

Gafatar mampu melakukan perekrutan massa yang besar, yang anggotanya berasal dari berbagai golongan, mulai dari masyarakat golongan ekonomi menengah ke bawah sampai golongan elit, seperti golongan terpelajar, mahasiswa, Dokter, PNS, tokoh masyarakat dan lain-lain ${ }^{2}$. Perekrutan tersebut berkaitan dengan pola pengorganisasian berbasis massa dan gerakan populisme melalui kegiatan-kegiatan sosial.

Selain cara perekrutannya melalui kegiatan-kegiatan sosial, Gafatar memiliki pandangan terhadap pertanian, dan kemandirian pangan Indonesia, bahkan berupaya melakukan swasembada pangan melalui program kedaulatan pangan secara swadaya tanpa bantuan pemerintah ${ }^{3}$, padahal pemerintah melalui Kementerian Pertanian telah menawarkan berbagai program pertanian kepada masyarakat, tetapi Gafatar memilih jalur mandiri dengan modal dan pelatihan yang mereka bentuk sendiri.

Gerakan civil society yang diusung Gafatar sebenarnya sebagai bentuk kepedulian pada permasalahan pangan Indonesia, dimana Gafatar beranggapan bahwa akan terjadi krisis pangan besar-besaran pada tahun 2020, sehingga pada Rapat Kerja Nasional yang ke-3, Gafatar mengangkat tema "Mewujudkan Nusantara Yang Damai Sejahtera Atas Nama Tuhan Yang Maha Esa, Melalui Peningkatan Program Kedaulatan Pangan Tahun 2015" sebagai topic pembahasan. ${ }^{4}$

Untuk pengejawantahan Program Kedaulatan Pangan Gafatar, maka Kalimantan dijadikan sebagai pilot project. Alasannya adalah karena pulau Kalimantan memiliki tanah yang subur dan strategis untuk bertani, serta harga lahannya pun relatif terjangkau, sehingga Kalimantan cocok untuk dijadikan sebagai tempat tujuan anggota Gafatar ${ }^{5}$.

Program kedaulatan pangan tersebut mengarah pada gerakan pertanian organik yang peduli sesama manusia dan alam semesta agar manusia dapat hidup damai dengan sesama dalam keseimbangan lingkungannya. Mengenai gerakan pertanian organik, banyak orang berkomentar: "Pertanian yang peduli kepada sesama dan alam semesta tampak seperti sebuah gerakan devosi keagamaan" (Wahono,2004).

2Budi Darmawan "Ini Gafatar cara merekrut anggotanya", diakses di http://palembang.tribunnews.com/2016/01/14/ini-cara-gafatar-merekrut-anggotanya, pada tanggal 14 Januari 2016pukul 03.43

3Fahmi Firdaus, "Gelar Rakernas, Gafatar siap wujudkan kedaulatan pangan”, diakses dari https:/news.okezone.com/read/2015/02/27/337/1111695/gelar-rakernas-gafatar-siapwujudkan-kedaulatan-pangan, pada tanggal27 Februari 2015pukul 19.35

${ }^{4}$ Ravishop, “GAFATAR : Persoalan pangan adalah persoalan hidup dan mati". Diakses

dari http//sayangi.com/berita/2017/03/09/GAFATAR-Persoalan-Pangan-adalah-persoalanHidup-dan-Mati/pada tanggal9 Maret 2017pukul 20.52

sibid 
Sehingga ada yang menganggap Gafatar sebagai kelompok fanatik ekslusif, dan pada akhirnya ada kelompok masyarakat yang pro dan kontra.

Konsep tersebut didesain dengan membangun sebuah basis pertanian dan perekonomian yang berpusat di suatu tempat, dengan berupa model kehidupan masyarakat kelompok kecil yang tinggal bersama yang didasarkan pada prinsip kehidupan bersama dengan tidak menentang kehidupan masyarakat pada umumnya melainkan berusaha membangun perubahan melalui alternatif-alternatif kehidupan yang dibangun dalam lingkungan kolektif. Gerakan ini sering disebut sebagai tipe gerakan komunal atau utopia.

Gafatar dapat dipandang sebagai gerakan social baru, sebab gerakan ini melakukan kritik terhadap pemerintah tetapi dengan cara yang berbeda, bukan dengan perlawanan resistensi melainkan dengan inovasi-inovasi dalam mengubah gaya hidup masyarakat, yang oleh Fadae (2009), disebut sebagai gerakan sosial baru.

Fokus kajian ini adalah untuk menganalisis dinamika perkembangan gerakan Gafatar berupa kritik aksi tanpa kekerasan melawan hegemoni penguasa dan neoliberalisme. Sehingga dalam studi ini digunakan paradigma dan teori gerakan sosial, sedangkan teori gerakan sosial yang digunakan untuk mengkaji dan menganalisis tentang kemunculan dan perkembangan Gafatar adalah dengan menggunakan pandangan Doug McAdam et.al, hal ini karena studi ini cenderung melihat bagaimana model pengorganisasian massa dengan melalui kristalisasi fenomenologi gerakan petani.

\section{PEMBAHASAN}

Gerakan sosial merupakan suatu tindakan kolektif dalam suatu masyarakat atau kelompok yang digerakan oleh orang-orang yang merasa tidak puas dengan struktur sosial yang ada dan berusaha untuk menyelesaikan suatu permasalahan yang dihadapi dengan mengubah struktur sosial tersebut untuk digantikan dengan struktur sosial yang baru (Ma'arif, 2010:52).

Gerakan Sosial mengalami perkembangan, baik dari sudut pandang kuantitas maupun kualitas, ketika masyarakat memasuki era modern sebagai respon terhadap kompleksitas tantangan kehidupan yang semakin dinamis. Perkembangan ilmu pengetahuan melahirkan tumbuhnya kesadaran kemanusiaan. Masyarakat semakin sadar akan kedudukan dan peranannya dalam dinamika kehidupan, namun disisi lain realitas kehidupan modern juga melahirkan berbagai masalah kemanusiaan. Untuk itu, kemodernan merupakan keadaan yang paling subur untuk tumbuhnya bermacam gerakan sosial, dalam berbagai bentuk dan isu. Gerakan sosial merupakan ciri dari masyarakat modern. (Azwar, 2015)

Menurut pendapat Bonner (dalam Fakih, 2004), di negara-negara berkembang, kajian tentang gerakan sosial dan transformasi sosial tidak dapat dipisahkan dari masalah pembangunan. Perbedaan kekayaan, kekuasaan dan kedudukan yang sangat tajam membentuk ketimpangan sosial yang selanjutnya menimbulkan pengalaman dan kesan eksploitasi, penindasan, ketidakadilan dan pencabulan hak yang menggerakan konflik kelompok. 
Di Indonesia Gerakan Sosial sudah berlangsung sejak era kolonialisme, tujuan dari gerakan sosial ini adalah sebagai upaya bentuk protes terhadap penguasa atau pemerintahan yang sedang berlangsung kala itu. Misalkan saja Gerakan Samin Surosentikno, pemberontakan petani di Banten 1888, dan yang lainnya. Dimana gerakan ini mengajarkan sebuah ideologi tertentu dalam upaya perlawanan secara pasif maupun aktif terhadap pemerintahan kolonial yang dipandang menyengsarakan rakyat.

Di era modernpun bermunculan gerakan sosial seperti gerakan sosial kaum tarekat, NII, Hizbuhtahir Indonesia, gerakan petani di Banten, Batang, Pekalongan, Cilacap dan Cipari, gerakan sosial di tanah Makasar "Batara Gowa", serta gerakan mistik Mukhdi Akbar di Kabupaten Selayar Sulawesi Selatan. Selanjutnya di tahun 2011-2015 lahir dan berkembangnya gerakan sosial Gafatar.

Gafatar merupakan gerakan sosial karena memiliki kesamaan persamaan tujuan hidup yakni memperoleh kehidupan yang lebih baik secara ekonomi dan sosial, dimana keanggotannya berasal dari berbagai daerah dan profesi, yang disatukan dalam sebuah organisasi. seperti apa yang dikatakan oleh Diani (dalam Nash 2000), bahwa "gerakan sosial memiliki ikatan ide dan komitmen bersama diantara para anggota atau konstituen gerakan itu walau mereka dibedakan dalam berbagai profesi, kelas sosial, dan lain-lain. Ada kesamaan kepercayaan dan perpaduan diantara mereka. Ada aksi bersama-sama dengan membawa isu yang bersifat conflictual. Ini berkaitan dengan penentangan atau desakan terhadap perubahan tertentu. Aksi tuntutan itu bersifat berkelanjutan tetapi tidak terinstitusi dan mengikuti prosedur rutin seperti yang dikenal dalam organisasi atau agama, misalnya".

Menurut Shihab (2004:2), perkembangan pergerakan sosial, memperlihatkan dua aspek yang menonjol, yaitu, pertama, aspek yang didorong oleh orientasi politis, kedua orientasi kebangkitan kultural rakyat Indonesia. Begitu juga dengan Gafatar yang memperlihatkan kedua aspek itu, yakni orientasi politis yang disebabkan karena adanya deprivasi relative dan kebangkitan pertanian yang merupakan profesi cultural masyarakat Indonesia sejak dulu.

McAdam, McCarthy, dan Zald, (2004;2) menjelaskan bahwa ada tiga faktor yang penting dalam mengkaji dan menganalisis tentang kemunculan dan perkembangan gerakan sosial. Ketiga faktor tersebut meliputi: (1) Political Opportunities, meliputi struktur peluang-peluang politik dan kendala-kendala yang menghambat gerakan; (2) Mobilizing Structures, meliputi bentuk dari organsasi, baik formal maupun informal, yang mendukung suatu peluang dan tindakan (aksi); (3) Cultural Framings, meliputi konstruksi sosial pengembangan bingkai kultural.

\section{Political Opportunities}

Ketidakpercayaan kepada pemerintah seringkali melahirkan gerakangerakandi masyarakat, seperti halnya Gafatar yang lahir sebagai upaya kebersamaan cita-cita dan tujuan yang ingin dicapai bersama oleh sekelompok orang sehingga membentuk sebuah organisasi yang lahir berdasarkan atas persamaan ide dan komitmen walau berasal dari berbagai status atau kelompok sosial yang berbedabeda. 
Yang unik dari pergerakan sosial Gafatar selain cara perekrutannya melalui kegiatan-kegiatan sosial ${ }^{6}$, Gafatar memiliki pandangan terhadap pertanian, ketahanan dan kemandirian pangan Indonesia, bahkan berupaya melakukan swasembada pangan melalui program Kedaulatan Pangan secara swadaya tanpa bantuan pemerintah 7 , padahal Pemerintah melalui Kementerian Pertanian telah menawarkan berbagai program pertanian kepada masyarakat, seperti Program Peningkatan Produksi Beras Nasional (P2BN), Pengembangan Usaha Agribisnis Perdesaan (PUAP), Lembaga Mandiri Mengakar ke Masyarakat (LM3), Percepatan Penganekaragaman Konsumsi Pangan (P2KP), Desa Mandiri Pangan (Desa Mapan) dan lain-lain ${ }^{8}$, tetapi Gafatar memilih jalur mandiri dengan modal dan pelatihan yang mereka bentuk sendiri.

Pilihan secara swadaya dalam program pertanian, bisa dikatakan sebagai bentuk penolakan dan ketidakpercayaan terhadap program-program pemerintah yang telah ditawarkan kepada masyarakat yang dinilai masih belum efektif ${ }^{9}$ sehingga membentuk program tandingan.

Masalah krisis pangan di Indonesia sampai sejauh ini masih belum teratasi, tingkat impor bahan pangan yang tinggi, minimnya lahan produksi pangan, rendahnya daya beli masyarakat, sulitnya mendapatkan modal dan disatu sisi tingginya angka kemiskinan menjadi fokus utama yang harus diperhatikan. Padahal Menurut Hariyadi (2011), memperhatikan karakteristik dan potensi yang dimiliki Indonesia khususnya mengenai keadaan, luas wilayah dan kondisi lingkungannya, maka Indonesia mempunyai peluang besar untuk mewujudkan kemandirian pangan.

Pakpahanet all (1993) mengemukakan bahwa perlu adanya upaya-upaya dan tindakan konkrit untuk membangun sebuah ideologi pembangunan pertanian berkeadilan yang dapat mempertemukan dan mengharmoniskan antara kepentingan negara (pemerintah) dengan kepentingan petani. Menurut Teddy et all (2016), pada dasarnya pembangunan pertanian yang ideal adalah dapat diwujudkan jika bersendikan pada "kemandirian" dan "keberpihakan", dalam pengertian petani seharusnya diberdayakan untuk mandiri dalam mengambil segala keputusan yang berkaitan dengan usaha pertaniannya dan pemerintah memberi dukungan dan keberpihakan untuk mewujudkan kemandirian tersebut.

Namun sejauh ini pemerintah justru tidak memberikan kebebasan kepada petani dalam membuka akses lahan pertanian dan kebebasan berorganisasi. Sepertinya pemerintah takut karena berpotensi politik. Pemerintah lebih banyak membuat kebijakan tentang produksi dan pasar.

${ }^{6}$ Budi Darmawan, loc.cit

${ }^{7}$ Kristian Ambarita“ini kata Eks Ketua Gafatar DIY soal program eksodus dan lahan garapan"diaksesdarihttps://anekainfounik.net/2016/01/13/ini-kata-eks-ketua-gafatar-diysoal-program-eksodus-dan-lahan-garapan/ pada tanggal 13 Januari 2016 pukul 09.01

${ }^{8}$ Program-program pemerintah dalam rangka mencapai 4 (empat) sukses pertanian dalam Rencana Strategis Kementerian Pertanian. (1) Peningkatan Swasembada dan Swasembada Berkelanjutan, (2) Peingkatan Diversifikasi Pangan; (3) Peningkatan Nilai Tambah, Daya Saing, dan Ekspor; (4) Peningkatan Kesejahteraan Pertanian.

${ }^{9}$ Fahmi Firdaus, loc.cit. 
Inilah yang melahirkan apa yang disebut sebagai deprivasi relatif, yaitu sebuah kekecewaan dan ketidakpuasan terhadap sebuah situasi yang pada akhirnya melahirkan usaha-usaha kolektif masyarakat untuk menuntut kesetaraan dan keadilan sosial. Upaya ini kemudian dimanifestasikan melalui Gafatar, sebuah oganisasi gerakan sosial yang melihat adanya kesempatan politik untuk mencapai cita-cita bersama.

Penjelasan di atas menggambarkan bahwa Gafatar merupakan bentuk kegelisahan masyarakat terhadap pola pemerintahan yang sedang berjalan, dimana Indonesia yang sudah lama merdeka masih belum bisa keluar dari belenggu kemiskinan dan persoalan-persoalan bangsa yang semakin tidak karuan. Banyak kasus korupsi, peradilan yang dimanipulasi, penyalahgunaan wewenang dan hal-hal lainnya yang membuat prihatin akan berlangsungnya bangsa Indonesia.

Jika dibandingkan negara-negara tetangga seperti Australia, Singapura dan Malasya, Indonesia masih tertinggal. Padahal Indonesia merdeka terlebih dahulu. Keadaan inilah yang kemudian menjadi alasan pembentukan Organisasi Gerakan Fajar Nusantara yang diprakarsai oleh 52 badan pendiri dengan tujuan sebagai organisasi yang bergerak di bidang kemasyarakatan.

Pada dinamika perkembangan Gafatar, gerakan ini mengalami berbagai kendala, seperti desas-desus dan pemberitaan menyudutkan yang disebarkan oleh media massa, membuat anggota Gafatar menjadi resah dan khawatir hidup di tengahtengah masyarakat. Terutama adalah isu yang mengatakan bahwa Gafatar merupakan jelmaan dari aliran Al-Qaidah Al-Islamiah yang telah divonis sebagai aliran sesat oleh MUI padatanggal 3 Oktober 2007 melalui Fatwa No. 04 Tahun 2007.

Kendala lainnya adalah adanya pemberitaan hilangnya seorang dokter perempuan bernama Rica Tri Handayani bersama anaknya yang masih balita pada akhir Desember 2015. Mereka kemudian ditemukan di Pangkalan Bun, Kalimantan Tengah. Berbagai laporan media menyebutkan, hilangnya dokter Rica diduga terkait dengan organisasi Gafatar. Menyusul hilangnya dokter Rica, sejumlah orang juga dinyatakan menghilang, dan lenyapnya mereka diduga terkait organisasi Gafatar ${ }^{10}$.

Selain itu, Gafatar dianggap akan membentuk kelompok separatis untuk mendirikan negara baru yang berpusat di Kalimantan. Negara baru itu bernama Negeri Karunia Tuhan Semesta Alam Nusantara, bahkan isunya sudah memiliki presiden, wakil presiden dan membagi wilayah menjadi 12 bagian beserta gubernurnya ${ }^{11}$.

Isu tentang makarini, mengisaratkan bahwa transmigrasi swadaya yang dilakukan Gafatar tak ubahnya seperti mencari suaka, seolah-olah Gafatar hidup dalam penindasan dan penjajahan neokolonial di negaranya sendiri. Kemudian melakuan migrasi ke pulau Kalimantan dan membentuk negara baru atau negara tandingan.

${ }^{10}$ Yanuar, "Dokter Rica ditemukan di Pangkalan Bun, Kondisi Masih Labil". Diaksesdarihttps://www.liputan6.com/news/read/2409091/dokter-rica-ditemukan-dipangkalan-bun-kondisi-masih-labil, pada tanggal 10 Mei 2018 Pukul 11.30

${ }^{11}$ Linda Trianita, dkk "Kepala Polri sebut Gafatar ingin dirikan negara sendiri" Tempo, edisi 26 Januari 2016 
Dua isu utama yang menjadi permasalahan Gafatar yaitu tuduhan sebagai aliran sesat dan upaya makar. Pihak pemerintah dan media cenderung melebihlebihkan isu tersebut, sehingga dalam pemahaman masyarakat ini bukanlah isu lagi melainkan fakta.

Ketua Gafatar Mahful Muis Tumanurung memang pernah mengatakan bahwa organisasi Gafatar bukanlah organisasi keagamaan melainkan organisasi sosial, sehingga anggotanya berasal dari berbagai macam agama dan aliran, tidak terkecuali mantan pengikut $\mathrm{Al}$-Qiyadah Al-Islamiah.

Gafatar merangkul eks anggota Al-Qiyadah Al-Islamiah tujuannya agar mereka tidak terlunta-lunta di masyarakat karena sudah dicap sebagai pengikut aliran sesat. Bersama Gafatar, harapannya eks Al-Qiyadah Al-Islamiah dapat menyusun kehidupannya kembali menjadi lebih baik.

Namun kecurigaan dan ketakutan dari pihak-pihak tertentu membuat seolaholah Gafatar sebagai tempat berkembangnya aliran Al-Qiyadah Al-Islamiah dengan membuat komunitas baru agar dapat leluasa beribadah dan mengembangkan ajarannya, serta mendoktrin anggota-anggota baru Gafatar untuk mengikuti ajaran $\mathrm{Al}$ Qiyadah Al-Islamiah.

Media juga memberitakan fenomena ini secara berlebihan dan bersifat lebih pada mendukung atau membuktikan kebenaran isu-isu yang beredar sehingga efeknya adalah perlakuan buruk yang diterima eks Gafatar di masyarakat seperti perlakuan diskriminatif, pengusiran, penolakan sehingga bisa dikatakan adanya kriminalisasi terhadap para eks Gafatar.

Konflik yang terjadi dalam kasus Gafatar, berbeda dengan konflik-konflik lainnya yang ada di Indonesia, yang biasanya berlatar belakang etnisitas. Kasus Gafatar ini dilatarbelakangi oleh hite spin yang muncul karena informasi-informasi yang di dapatkan masyarakat menyudutkan kelompok Gafatar, sehingga melahirkan asumsi-asumsi negatif terhadap kelompok ini. Asumsi-asumsi itu diantaranya anggapan masyarakat bahwa Gafatar adalah aliran sesat dan merupakan organisasi makar.

Media massa memiliki peran yang sangat signifikan dalam penyebaran informasi, karenanya apabila media massa menyebarkan berita hanya mengejar trend dan popularitas saja tanpa melihat kebenaran yang ada maka akan berdampak sangat buruk apalagi jika masuk dalam domain nasional atau bahkan Internasional.

Inilah yang terjadi dalam kasus Gafatar, media massa cenderung memberitakan apa yang sedang trend saat itu. Saat Gafatar diisukan sebagai komunitas sesat maka media massapun gencar memberitakan Gafatar sebagai aliran sesat, saat Gafatar diisukan sebagai oganisasi makar maka media Massa memberitakan secara besar-besar bahwa Gafatar sebagai organisasi makar sehingga membentuk stigmatisasi masyarakat yang menganggap sesat Gafatar.

\section{Mobilizing Structures}

Pada tanggal 14 Agustus 2011 secara resmi Gafatar di bentuk di Jakarta dengan tujuan sebagai organisasi yang bergerak di ranah kemasyarakat dengan berlambangkan Bendera "Fajar yang terbit dari Timur dengan dua belas sinar". Legalitas 
pendirian Organisasi Gafatar terdapat dalam UUD 1945 pasal 28, UU No. 8 tahun 1985 tentang Orkemas dan Akte pendirian ormas No. 01 tanggal 05 September 2011. ${ }^{12}$

Adapun Visi dan Misi Gafatar adalah sebagai berikut: Visi

Terwujudnya tata kehidupan masyarakat, bangsa dan negara yang damai sejahtera, beradab, berkeadilan dan bermartabat di bawah naungan Tuhan Yang Maha Esa melalui penyatuan nilai-nilai luhur bangsa, peningkatan kualitas ilmu dan intelektualitas, serta pemahaman dan pengamalan nilai-nilai universal agar menjadi rahmat bagi semesta alam.

Misi

Memperkuat solidaritas, kebersamaan, persatuan, dan kesatuan khususnya antar sesama elemen bangsa Indonesia serta dunia pada umumnya. Selain itu, juga memupuk saling pengertian dan kerja sama antar sesama lembaga yang memiliki kepedulian dan perhatian terhadap upaya perdamaian dan kesejahteraan dunia. ${ }^{13}$

Setelah Gafatar terbentuk, implementasi kegiatan yang dilakukan adalah berupa kegiatan sosial dan kemasyarakatan seperti kerja bakti, donor darah, sunatan massal dan bantuan modal usaha. Kegiatan sosial ini tidak hanya berlangsung di Jakarta saja, melainkan berkembang ke beberapa daerah di Indonesia.

Kegiatan-kegiatan sosial yang dilakukan Gafatar terkadang menggandeng organisasi lainnya seperti masyarakat Pepabri (Persatuan Purnawirawan Angkatan Bersenjata Republik Indonesia) di Bandung, Yayasan Pijar Insani di Cianjur, Palang Merah Indonesia (PMI) Bekasi, Pemerintah Daerah Pamekasan Madura, Forum Ormas Purwakarta, Pemerintah Daerah Depok, dan lainnya.

Kegiatan Bakti Sosial inilah yang membuat banyak masyarakat tertarik bergabung dengan Gafatar dan mulai mengenal Gafatar sebagai organisasi yang berani membuat gebrakan untuk melakukan perubahan bagi masyarakat kecil yang kesulitan secara ekonomi.

Ini menunjukan bahwa masyarakat saat itu menerima Gafatar dengan baik. Selama hampir 4 tahun Gafatar berkembang dan tidak ada permasalahan baik dengan masyarakat maupun dengan pemerintah, semua kegiatan berjalan normal tidak ada kendala, tindakan anarkis dari masyarakat, maupun tendensi-tendensi lainnya. Penerimaan dari masyarakat inilah yang pada akhirnya membuat banyak anggota masyarakat tertarik bergabung dengan Gafatar

Perkembangan Gafatar bisa dikatakan cepat padahal awalnya tidak banyak yang tahu tentang organisasi ini, lambat laun anggota Gafatar hampir ada disetiap kota / kabupaten di Indonesia. Gafatar mudah diterima di kalangan masyarakat dan berkembang ke daerah-daerah hingga pada februari 2015 Gafatar telah memiliki 24 Dewan Perwakilan Daerah serta perwakilan di daerah-daerah kecil yang tersebar dari Aceh sampai Papua.

12“Apa itu Gerakan Gajar Utama (GAFATAR)?”. Gafatarian.blogspot.co.id.diakses pada11 Januari 2016. Namun web blog tersebut tidak bisa diakses lagi

13ibid 
Pada Tanggal 26 Februari 2015, Gafatar mengadakan Rakernas ke tiga yang bertempat di Gedung Balai Sudirman, Jalan Prof. Sahardjo, Jakarta Selatan. dengan Tema "Mewujudkan Nusantara Yang Damai Sejahtera Atas Nama Tuhan Yang Maha Esa, Melalui Peningkatan Program Kedaulatan Pangan Tahun 2015". Rakernas ini merupakan Program Kerja Tahunan yang membahas tentang program swasembada pangan. Dasar dari program ini adalah Gafatar melihat akan terjadi krisis pangan besar-besaran yang diperkirakan akan terjadi pada tahun 2020.

Dalam perkembangannya sebagai pengejawantahan dari Program Kedaulatan Pangan, maka Kalimantan dijadikan tempat untuk pelaksanaan Program ini, karena Pulau Kalimantan memiliki tanah yang subur dan strategis untuk bertani, serta harga lahannya pun relatif terjangkau, sehingga Kalimantan cocok untuk dijadikan sebagai tempat tujuan transmigrasi oleh anggota Gafatar.

Program-program Gafatar tersebut didesain dengan membangun sebuah tempat sebagai basis pertanian dan perekonomian di kalangan kelompok kecil yang dilakukan dengan mendirikan lingkungan kolektif, dimana terdapat sekelompok orang tinggal bersama di dalamnya, memiliki ikatan kerja sama yang didasarkan pada prinsip egaliter.

Program ini bentuknya adalah transmigrasi swadaya, sehingga tidak ada bantuan dari pemerintah. Yaitu dengan menerapkan iuran sukarela bagi pesertanya, tidak ada pungutan paksaan. Iuran tersebut berasal dari hasil penjualan benda bergerak dan tidak bergerak miliknya yang digunakan sebagai modal bertani di Kalimantan ${ }^{14}$.

Anggota Gafatar yang mengikuti Program Kedaulatan pangan, berasal dari berbagai daerah dengan latar belakang profesi, agama, dan organisasi yang berbedabeda. Tujuan mereka mengikuti program ini didominasi alasan ekonomi, dimana di tempat asal mereka tidak mendapatkan pekerjaan yang layak, jauh dari kesejahteraan. Harapan mereka mengikuti program kedaulatan pangan ini adalah agar dapat meningkatkan taraf hidup ${ }^{15}$.

Ketika di Kalimantan anggota Gafatar membeli dan menyewa tanah untuk ditempati serta membuka ladang dan persawahan. Hubungan antara anggota Gafatar dengan masyarakat setempat sebenarnya cukup harmonis, mereka membaur dan bersosialisasi dengan masyarakat, bahkan eks Gafatar di berikan izin untuk mengelola tanah adat yang terbengkalai tidak dirawat. ${ }^{16}$

Ini membuktikan bahwa anggota Gafatar sebenarnya diterima dengan baik oleh masyarakat sekitar, hanya karena adanya informasi dari luar yang menyudutkan kelompok Gafatar menyebabkan situasi berubah dari masyarakat yang mendukung menjadi menolak keberadaan anggota Gafatar di Kalimantan yang disebabkan karena munculnya isu aliran sesat dan isu makar yang berkembang di masyarakat.

\footnotetext{
${ }^{14}$ Kristian Ambarita, loc.cit

${ }^{15}$ Switzi Sabandar" untuk program pangan, Gafatar punya 5 ribu Ha di Kalimantan", diaksesdarihttps://nasional.tempo.co/read/737775/untuk-progam-pangan-gafatar-punya-5ribu-ha-di-kalimantan pada tanggal 20Januari 2016 pukul 12.19

16ibid
} 
Ketika mereka datang pertama kali di Kalimantan mereka disambut dengan baik oleh masyarakat setempat, anggota Gafatar membeli dan menyewa tanah untuk ditempati dan membuka ladang dan persawahan. Namun situasi berubah dari masyarakat yang mendukung menjadi menolak keberaan anggota Gafatar di Kalimantan. Disebabkan karena munculnya isu aliran sesat dan isu makar yang dilakukan Gafatar yang berkembang di masyarakat.

Gafatar membubarkan diri pada tanggal 13 Agustus 2015 melalui kongres luar biasa karena berbagai pertimbangan dan alasan. Berikut alasan secara garis besar yang menyebabkan pembubaran Gafatar :

1. Pembubaran dilakukan untuk menyikapi dinamika dan perkembangan informasi yang terkesan menyudutkan ormas Gafatar.

2. Gafatar membubarkan diri setelah tidak mendapatkan surat keterangan terdaftar (SKT) dari Kemendagri. ${ }^{17}$

Anggota Gafatar yang terlanjur menjalankan program kedaulatan pangan di Kalimantan berubah menjadi kelompok tani. Walaupun sudah bubar dan menjadi kelompok tani, keberadaan eks Gafatar masih menjadi sorotan tajam bagi media dan masyarakat. Puncaknya adalah penyerangan, perusakan dan pembakaran perkampungan kelompok tani eks Gafatar di Mempawah Kalimantan barat.

Kriminalisasi bagi eks Gafatar bisa saja diasumsikan sebagai imbas untuk kepentingan kelompok tertentu dengan mengkambing hitamkan Gafatar. Gafatar memiliki program unggulan yaitu Ketahanan dan kedaulatan pangan atau swasembada pangan, yang mungkin saja ini mengancam bagi para pedagang besar dalam usahanya sehingga melakukan sebuah trik untuk membubarkan Gafatar, atau mungkin ada faktor-faktor bernuansa politik, yaitu adanya ketakutan Gafatar yang merupakan organisasi sosial kemasyarakatan akan berubah menjadi sebuah partai besar yang mengancam partai-partai lain yang sudah ada saat ini. Walaupun asumsi ini sangat jauh, namun politik sangat keras dan untuk mencapai tujuannya bisa dilakukan dengan berbagai cara.

\section{Cultural Framings}

Gafatar adalah sebuah organisasi yang di vonis sesat sejak 2016 oleh pemerintah Indonesia ${ }^{18}$. Isu-isu seputar ajaran atau ideologi, upaya makar dan kasus

\footnotetext{
17Wijaya Kusuma, "Gafatar sudah bubar sejak 2015". Diaksesdarihttps://regional.kompas.com/read/2016/01/12/14323651/.

Gafatar.Sudah.Bubar.sejak.2015, pada tanggal 12 Januari 2016 pukul 14.32

18 Fatwa MUI Nomor 6 Tahun 2016 Tentang Aliran Gerakan Fajar Nusantara (GAFATAR).menyatakan bahwa Gafatar sebagai organisasi sesat dan menyesatkan. setelah melakukan kajian menyeluruh. MUI melihat Gafatar sebagai metamorfosis dari aliran agama bentukan Ahmad Mussadeq yaitu dari Al-Qiyadah Al-Islamiyah menjadi Komunitas Millah Abraham (Komar). Dan pemerintah telah menetapkan larangan aktivitas Gerakan Fajar Nusantara melalui Surat keputusan bersama (SKB) yang resmi dikeluarkan oleh Menteri Agama, Jaksa Agung dan Menteri Dalam Negeri (Mendagri). Larangan itu dikeluarkan berdasarkan surat keputusan Nomor Kep-043/A/JA/02/2016 dan Nomor:223-865 Tahun 2016 tentang Perintah dan Peringatan kepada Mantan Pengurus, Mantan Anggota, Pengikut,
} 
penculikan menjadi permasalahan yang menyebabkan organisasi ini dilarang oleh pemerintah.

Namun jika melihat visi dan misi Gafatar sebenarnya sama seperti organsasi sosial pada umumnya yang memiliki kepedulian terhadap kondisi sosial bangsa, hanya pemerintah sepertinya takut dengan Ideologi keagamaan yang berkembang dalam organisasi yang dikatakan oleh MUI sebagai metamorfosa dari Al-Qaidah AlIslamiah, sebuah ajaran Ahmad Musadeq, yaitu ajaran yang mencampuradukkan agama Abraham (Millah Ibrahim), yang sudah di vonis sesat sejak 2007, serta khawatir dengan pergerakan yang dianggap pemerintah berpotensi makar dengan Kalimantan sebagai basisnya.

Sayangnya apa yang dilakukan oleh Gafatar, di mata pemerintah dikategorikan sebagai gerakan yang negatif. Walhendri Azwar (2015;28) mengatakan bahwa "sebagai tujuan gerakan sosial, perubahan sosial dapat bersifat positif, yaitu memperkenalkan hal-hal yang baru, dan juga bersifat negatif, yaitu menghentikan, mencegah, dan mengembalikan arah perubahan dari proses yang tidak berkaitan dengan gerakan sosial itu sendiri.

Barangkali pemerintah menganggap Gafatar sebagai New Religion Movement (NRM), jika dikaitkan dengan ajaran ideologinya adalah Millah Abraham, seperti mengacu pada tulisan Al Makin $(2017 ; 6)$ yang menjelaskan dua faktor yang memberikan dorongan munculnya NRM. Pertama gerakan kenabian milenarianisme dan mesianisme mengajarkan faham reinkarnasi, pembaharuan spiritual, ratu adil dan erucakra (penyelamat). Kedua, 'agama populer' yang mengkombinasikan berbagai unsur tradisi agama di dunia, misalnya Islam, Kristen, dan kepercayaan setempat.

Fenomena Gafatar memuncak ketika terjadi penyerangan pemukiman eks Gafatar $^{19}$ pada tanggal 19 Januari 2016Terjadi perusakan, pembakaran rumah dan pengusiran warga eks Gafatar yang berjumlah lebih dari 700 orang yang berlangsung di desa Moton Asam, Moton Panjang, Antibar, Pasir dan Kuala Secapa Kecamatan Menpawah Timur Kabupaten Menpawah Provinsi Kalimantan Barat ${ }^{20}$. Sebenarnya eks Gafatar bingung kenapa mereka diserang, padahal Gafatar sendiri sudah bubar sejak 2015, status mereka tidak lagi anggota Gafatar melainkan kelompok tani, lagi pula Gafatar bergerak dibidang sosial bukan agama apalagi makar. "Kami bukan teroris, kami tidak ngebom, kami hanya bertani, kenapa kami diusir?" kata Agus eks Petani Gafatar ${ }^{21}$.

Pemerintah kemudian memulangkan eks Gafatar ke daerah asal mereka masing-masing pasca kerusuhan di Mempawah. Pemulangan eks Gafatar ke daerah

\footnotetext{
dan/atau Simpatisan Organisasi Kemasyarakatan Gerakan Fajar Nusantara atau Dalam Bentuk Lainnya untuk Menghentikan Penyebaran Kegiatan Keagamaan yang Menyimpang dari Ajaran Pokok Agama Islam.

${ }^{19}$ eks Gafatar adalah mantan anggota Gafatar yang mengikuti program Kedaulatan

Pangan Gafatar di Kalimantan. Gafatar sendiri sudah membubarkan diri sejak tanggal 14 Agustus 2015.

${ }^{20}$ Fira, loc.cit

${ }^{21}$ Wawancara dengan Agus (Nama Samaran) eks Petani Gafatar yang berasal dari

Kasihan Bantul Yogyakarta
} 
asalnya ternyata tidak semuanya berjalan dengan mulus, diantaranya ada penolakan dari eks Gafatar sendiri, alasannya karena semua harta yang dimiliki di daerah asal sudah dijual untuk investasi usaha pertanian di Kalimantan. ${ }^{22}$ Warga asal daerah eks Gafatar juga melakukan penolakan terhadap rencana pemulangan eks Gafatar dengan alasan takut menyebarkan ideologi yang menyesatkan ${ }^{23}$. Selain itu pemerintah pun tidak bisa memenuhi janjinya untuk mengembalikan aset mereka di Kalimantan sehingga menambah beban bagi kelompok tani eks Gafatar.

Sekarang ini, eks Gafatar oleh sebagian masyarakat tertentu masih dipandang sebagai sesuatu yang harus dihindari dan dijauhi, padahal mereka memiliki hak untuk bersosialisasi dan mendapatkan hak-haknya sebagaimana warga negara lainnya.

Informasi yang berkembang adalah ditemukannya sekelompok masyarakat yang masih memvonis eks Gafatar sebagai orang atau kelompok dari golongan yang sesat. Sehingga dalam pergaulannya di masyarakat mereka dipersulit mulai dari adanya diskriminasi, pengusiran, pencabutan KTP dan pencantuman sebagai orang yang pernah terlibat dalam tindakan kriminalitas yang tertuang dalam Surat Keterangan Catatan Kepolisian (SKCK) ${ }^{24}$.

Kondisi ini sangat mempersulit eks Gafatar untuk bisa berkembang dan hidup layak sebagaimana mestinya. Mereka kesulitan dalam bertempat tinggal, kesulitan mendapatkan pekerjaan karena terbentur SKCK yang bermasalah, dan perlakuan diskriminatif di masyarakat. Penyebabnya adalah stigma yang melekat pada eks Gafatar masih negatif.

Informasi yang terlalu menyudutkan Gafatar sebagai aliran sesat menjadikan banyak kelompok organisasi menolak kehadiran Gafatar diantaranya Majelis Ulama Indonesia (MUI), Muhammadiyah, Nahdahtul Ulama (NU), Front Pembela Islam (FPI), Ikatan Da'i Indonesia (IKADI), Badan Komunikasi Pemuda Remaja Masjid Indonesia (BKPRMI), Dewan Adat Dayak (DAD) se-Kalimantan dan ratusan masyarakat dari Kabupaten Mempawah, juga melakukan unjuk rasa di depan Kantor DPRD Provinsi Kalimantan barat guna menolak dikembalikannya warga eks Gafatar ke Kalimantan barat dalam bentuk apapun.

Namun upaya pembelaan diri terus dilakukan oleh petinggi dan pengurus serta anggota eks Gafatar yang berani bersuara melalui media massa, yang intinya masalah kepercayaan atau agama adalah hak masing-masing anggota sesuai dengan kepercayaannya masing-masing, Gafatar hanya sebagai organisasi kemasyarakatan bukan keagamaan.

Namun pemerintah telah menetapkan larangan aktivitas Gerakan Fajar Nusantara melalui Surat keputusan bersama (SKB) yang resmi dikeluarkan oleh Menteri Agama, Jaksa Agung dan Menteri Dalam Negeri (Mendagri). Larangan itu

\footnotetext{
${ }^{22}$ Maya AyuPuspitasari, dkk“Mereka bingung jika pulang ke kampung halaman"

Tempo,edisi Januari 2016

${ }^{23}$ Farid Assifa“Warga Tiga Kecamatan di Bantul tolak eks Gafatar", diaksesdarihttps://regional.kompas.com/read/2016/02/03/01103591/Warga.Tiga.Kecamatan.di .Bantul.Tolak.Eks.Gafatar, pada tanggaltanggal 3 Februari 2016pukul 01.10

${ }^{24}$ Lihat tulisan Azis Anwar Fachrudin "Gafatar dalam Narasi: Melampaui Isu Agama" telah di publikasiku di http://crcs.ugm.ac.id/ pada tanggal 24 Oktober 2016
} 
dikeluarkan berdasarkan surat keputusan Nomor Kep-043/A/JA/02/2016 dan Nomor:223-865 Tahun 2016 tentang Perintah dan Peringatan kepada Mantan Pengurus, Mantan Anggota, Pengikut, dan/atau Simpatisan Organisasi Kemasyarakatan Gerakan Fajar Nusantara atau Dalam Bentuk Lainnya untuk Menghentikan Penyebaran Kegiatan Keagamaan yang Menyimpang dari Ajaran Pokok Agama Islam.

Kondisi ini sangat mempersulit eks Gafatar untuk bisa berkembang dan hidup layak sebagaimana mestinya. Mereka kesulitan untuk diterima di daerah asal ataupun di daerah mana saja eks Gafatar tinggal akan selalu mendapat perlakuan yang diskriminatif. Persoalan ini berkembang ke arah pengangguran, sulitnya pendidikan bagi anak-anak eks Gafatar, masalah sosial, kemiskinan, pelanggaran HAM dan lainlain. Imbas dari konflik ini tidak hanya terjadi di Menpawai saja tetapi diberbagai daerah yang diketahui terdapat warga eks Gafatar terjadi ketegangan dan tidak bisa dihindari terjadinya konflik manifes.

Terkait dengan fenomena ini, saya melihat masyarakat terbagi dalam tiga kategori yaitu masyarakat yang menolak Gafatar, masyarakat yang menerima Gafatar dan masyarakat sebagai korban. Masyarakat yang menolak adalah masyarakat yang sudah terprovokasi oleh isu-isu yang beredar sehingga mereka memiliki stereotip negatif tentang Gafatar. Umumnya masyarakat yang menolak ini adalah masyarakat yang berasal dari golongan keras, terutama dalam hal keyakinan sehingga apapun yang mereka lakukan adalah sebagi bentuk jihad. Ada lagi yang menolak karena alasan NKRI, dimana Gafatar dalam pandangan mereka sebagai organisasi yang akan melakukan makar sehingga harus dibubarkan dan dilarang berkembang.

Masyarakat yang menerima Gafatar adalah masyarakat yang masih percaya bahwa Gafatar adalah organisasi yang tidak menyimpang dan hanyalah sebagai korban dari keputusan yang salah oleh pemerintah sehingga berdampak negatif sehingga menyebabkan hilangnya hak-hak eks Gafatar sebagai warga negara, dan masyarakat yang simpatik terhadap warga eks Gafatar yang mengalami diskriminasi. Ada pula masyarakat yang melihat bahwa fenomena Gafatar ini tidak lain hanyalah permainan politik saja yang mencoba mengambinghitamkan Gafatar sebagai sebuah aliran yang menyimpang.

Warga Gafatar yang sudah mendiami suatu tempat di Kalimantan dan sudah membaur dengan masyarakat lokal namun keberadaannya terusik oleh masyarakat yang menolak mereka, menjadi korban dari sebuah kebijakan. Akibatnya hak-hak mereka sebagai warga negara yang harusnya bisa hidup tenang dan nyaman harus terampas oleh efek pemberitaan negatif serta penolakan dari masyarakat yang sudah terprovokasi.

Daerah konflik yang mencuat di media massa adalah di Menpawai Kalimantan Barat, namun sebenarnya wilayah konflik gafatar dimulai dari beberapa daerah di Kalimantan terutama di Menpawai namun awalnya masih konflik laten, dimana konflik muncul secara bertahap namun tidak tampak atau tersembunyi. Konflik ini wajar karena Gafatar merupakan pendatang baru sehingga ada rasa kecemburuan sosial dari warga lokal.

Kemudian konflik laten ini berubah menjadi konflik manifes setelah isu-isu tentang gafatar sebagai aliran sesat dan organisasi makar di dengar oleh warga sekitar, 
mulailah adanya ketegangan-ketegangan namun belum mengarah kepada kekerasan. Mulailah muncul kelompok yang berusaha mengganggu komunitas eks Gafatar berupa intimidasi agar eks Gafatar segera meninggalkan Menpawai.

Namun intimidasi tersebut tidaklah ditanggapi dengan serius oleh eks Gafatar hingga akhirnya kelompok yang menentang eks Gafatar bersama dengan masyarakat lokal yang terprovokasi merasa geram dan melakukan upaya pengusiran sehingga terjadi pembakaran, perusakan, pengusiran, penjarahan, dan penghancuran barangbarang milik eks Gafatar ${ }^{25}$. Konflik ini mengarah ke level kekerasan dan bersifat destruktif maka konflik ini disebut sebagai konflik manifes agresif.

Berdasarkan model konflik eskalasi Aggresor-Defender, warga yang melakukan perusakan disebut sebagai Agresor dan kelompok eks Gafatar sebagai Defender. Dimana keinginan dari Agresor sebagai pihak yang kuat tidak dituruti oleh Defender sehingga Agresor meningkatkan aksinya melalui tindakan destruktif (merusak).

Agresor-agresor lain pun muncul salah satunya Dewan Adat Dayak (DAD) seKalimantan menyatakan penolakannya terhadap eks Gafatar di Kalimantan, dan siap untuk melawan Komnas HAM dan Kontras. Sementara itu, ratusan masyarakat dari Kabupaten Mempawah, juga melakukan unjuk rasa di depan Kantor DPRD Provinsi Kalimantan barat guna menolak dikembalikannya warga eks Gafatar ke Kalimantan barat dalam bentuk apapun.

\section{Problem Solving yang ditawarkan}

Berdasarkan penjelasan dari tiga faktor di atas, maka dapat dilihat bahwa dalam melakukan perlawanan, Gafatar melakukan dengan dua cara yaitu melalui tindakan, berupa gerakan utopia dan oposisi, yakni membuat program tandingan. Hal ini senada dengan pernyataan Hollander dan Einwohner (2004) yang menyatakan bahwa secara umum ada dua elemen inti dalam perlawanan di dalam gerakan sosial, yakni: (1) Tindakan (action); dan (2) Oposisi (opposition). Tindakan (action) dipahami dalam konteks yang lebih luas, yakni mengacu tingkah laku aktif (active behavior), apakah itu bersifat verbal, kognitif, maupun fisik. Sementara oposisi (oppostion) mengacu pula kepada istilah-istilah lain, seperti: membalas (counter), bertentangan (contradict), perubahan sosial (social change), penolakan (reject), tantangan (challenge), subversif (subversive), dan kerusakan dan/atau gangguan (damage and/or disrupt).

Tindakan dan oposisi yang dilakukan Gafatar, harusnya di terima pemerintah sebagai kritikan keras untuk memperbaiki kinerja agar program-program pemerintah ke depannya bias diterima oleh masyarakat, sehingga tidak perlu lagi adanya program tandingan, dan juga tidak menjadikan permasalahan ini berkepanjangan sehingga merugikan masyarakat anggota Gafatar, bahkan masih menyisakan berbagai permasalahan, seperti diskriminasi, pelanggaran HAM, dan penyelesaian asset di Kalimantan yang belum tuntas.

Penanganan permasalahan Gafatar harus membutuhkan campur tangan pihak ketiga yang netral. Karena jika tidak demikian yang ada hanya muncul kelompok agresor (penolak Gafatar) yang menindas kelompok defender (Gafatar), tentu saja

25Pernyataan Andre (eksanggotaGafatar Bantul) dalamwawancaradenganpeneliti. 
pemenangnya adalah kelompok aggresor karena paling kuat dan yang dirugikan adalah kelompok defender. Solusi yang didapatkan bukan win-win melainkan win-lose.

Sebenarnya banyak pendekatan yang sudah dilakukan dalam resolusi konflik Gafatar diantaranya ada pendekatan Agama, pendekatan melalui lembaga peradilan, pendekatan melalui pemerintah, pendekatan dengan bantuan pihak ketiga dan pendekatan militer. Namun pendekatan-pendekatan ini justru bertendensi lebih menjerumuskan dan menyalahkan kelompok Gafatar karena bernuansa politis dan disetir oleh pihak pendukung kelompok agresor.

Problem solving yang ditawarkan dalam tulisan ini adalah untuk menyelesaikan permasalahan ini, baiknya menggunakan pendekatan psikologi sosial. Pemerintah tidak kemudian menekan agar eks Gafatar mengakui tuduhan-tuduhan mereka dan kemudian mengadili dengan tidak cukup bukti. Pemerintah juga harus mengantisipasi agar tidak terjadi konflik yang berkepanjangan sehingga merugikan eks Gafatar dan merehabilitasi nama baik mereka di masyarakat sehingga mereka dapat kembali diterima sebagai bagian yang utuh di masyarakat.

\section{KESIMPULAN}

Gafatar merupakan gerakan sosial baru di era postmodern saat ini sebagai fenomena yang hidup di negara dunia ketiga. Keberanian Gafatar dalam mengangkat isu kedaulatan pangan menjadi icon yang menarik banyak massa untuk bergabung. Kemudian dalam perkembangannya, gerakan ini harus berhadapan dengan lingkaran kebencian (hite spine) masarakat yang tercipta karena isu-isu seputar ideologi, makar, dan kasus penculikan.

Konsep kedaulatan pangan tersebut didesain dengan membangun sebuah basis pertanian dan perekonomian yang berpusat di Kalimantan, dengan membuat model kehidupan masyarakat utopia yang tinggal bersama melakukan swasembada pangan yang didasarkan pada prinsip kehidupan bersama.

Analisis tentang kemunculan dan perkembangan Gafatar, digunakan pandangan McAdam, McCarthy, dan Zald yaitu: (1) Political Opportunities, meliputi struktur peluang-peluang politik dan kendala-kendala yang menghambat gerakan; (2) Mobilizing Structures, meliputi bentuk dari organsasi, baik formal maupun informal, yang mendukung suatu peluang dan tindakan (aksi); (3) Cultural Framings, meliputi konstruksi sosial pengembangan bingkai kultural.

Kesempatan politik muncul dari derivasi relative berupa ketidakpercayaan terhadap program-program pemerintah yang telah ditawarkan kepada masyarakat yang dinilai masih belum efektif, sehingga melahirkan usaha-usaha kolektif masyarakat untuk menuntut kesetaraan dan keadilan sosial yang dimanifestasikan melalui Gafatar. Gafatar memiliki pandangan berbeda terhadap kemandirian pangan Indonesia, bahkan berupaya melakukan swasembada pangan melalui program Kedaulatan Pangan secara swadaya tanpa bantuan pemerintah padahal pemerintah sendiri memiliki program-program pertanian.

Kendala-kendala yang menghambat gerakan Gafatar adalah adanya desasdesus yang menyudutkan Gafatar seperti isu aliran sesat yang diarahkan kepada Gafatar sebagai metamorfosa Al-Qiyadah Al-Islamiah sebuah ajaran Ahmad Musadeq 
yang dipandang sesat oleh pemerintah, banyaknya isu penculikan yang ditujukan kepada Gafatar dan tuduhan upaya pendirian negara baru yang berpusat di Kalimantan.

Structur Mobilizazing gerakan Gafatar diwujudkan melalui (1) Pembentukan organisasi Gerakan Fajar Nusantara (Gafatar) pada tanggal 14 Agustus 2011; (2) Perkerutan anggota baru melalui aksi-aksi sosial seperti kerja bakti, donor darah, sunatan massal dan bantuan modal usaha, (3) Membentuk jaringan kerjasama dengan berbagai LSM dan pemerintah daerah; dan (3) aksi kolektif program kedaulatan pangan di Kalimantan yang diikuti oleh berbagai anggota dari berbagai daerah dan profesi dengan membentuk komunitas yang mampu melakukan swasembada pangan sendiri.

Sedangkan cultural framing, tercipta melalui isu-isu yang ditujukan kepada Gafatar sehingga menyebabkan terbentuknya stigma negatif masyarakat terhadap organisasi Gafatar dan pada akhirnya menyebabkan terjadinya aksi pembakaran dan perusakan di perkampungan petani Gafatar di desa Moton Asam, Moton Panjang, Antibar, Pasir dan Kuala Secapa Kecamatan Menpawah Timur Kabupaten Menpawah Provinsi Kalimantan Barat serta penolakan-penolakan di berbagai daerah bahkan di daerah asal anggota Gafatar. Terkait dengan fenomena ini, masyarakat terbagi dalam tiga kategori yaitu masyarakat yang menolak Gafatar, masyarakat yang menerima Gafatar dan masyarakat sebagai korban.

\section{DAFTAR PUSTAKA}

SumberBuku dan Jurnal

Azwar, Welhendri. 2015. Gerakan Sosial Kaum Tarekat. Padang: Imam Bonjol Press

Diani, Mario. 2000. The Concept of Social Movement. Dalam Nash, Kate. Reading in contemporary political sociology. Blackwell. Oxford, hlm 154-176.

Dirhamsyah, Tedy., Mulyo J.H., Darwanto, D.H., dan Hartono, Slamet. 2016. KetahananPangan, KemandirianPangan dan Kesejahteraan Masyarakat Daerah Rawan Pangan di Jawa.Yogyakarta: Plantaxia

Fadaee, Simin. 2010. Environmental Movement in Iran: Application of The New Social Movement Theory in The non-European context. Social Change Journal. Volume 41 (1). Page 79-96. Sage Publication.

Fakih, Mansoer. 1997. Analisis Gender dan Transformasi Sosial. Yogykarta : Pustaka Pelajar.

Haryadi, P. 2011. Menuju Kemandirian Pangan: Ketahanan Pangan Berbasis Sumber Daya Lokal. Southeast Asian Food and Agricultural Science and Science and Technology (SEAFAST) Center, LPPM IPB.

Hollander, Jocelyn A.; \& Einwohner, Rachel L. 2004. Conceptualizing Resistentance. Sociological Forum. Vol 19. N0.4 (Des. 2004), pp. 533-554

Maarif, Syamsul. 2010. Perilaku Kolektif Gerakan Sosial. Yogyakarta: Gress Publishing 
Makin, Al. 2017. Nabi-nabi Nusantara, Kisah Lia Eden dan lainnya. Yogyakarta: SUKAPress.

McAdam, Doug; McCarthy, John D; \& Zald, Mayer N. 2004. Comparative Perspectives on Social Movements: Political Opportunities, Mobilizing Structure, and Cultural Framings. Cambridge: Cambridge University Press.

Pakpahan, A., et all, 1993. Penelitian Tentang Ketahan Pangan Masyarakat Berpendapatan Rendah. Bogor: Monograph Series No. 14 Pusat Penelitian Sosial Ekonomi Pertanian.

Shihab, Alwi. 2002. Membendung Arus: Respons Gerakan Muhammadiyah Terhadap Penetrasi Misi Kristen di Indonesia. Jakarta: Mizan.

Wahono, Francis, dkk. 2004. Pangan, Kearifan Lokal dan Keanekaragaman Hayati. Yogyakarta: CPRC

\section{Sumber Koran dan Internet}

Ambarita, Kristian "ini kata Eks Ketua Gafatar DIY soal program eksodus dan lahan garapan”. 13 Januari 2016 https://anekainfounik.net/2016/01/13/ini-kata-eksketua-gafatar-diy-soal-program-eksodus-dan-lahan-garapan/

Assifa, Farid. "Warga Tiga Kecamatan di Bantul tolak eks Gafatar". 3 Februari 2016. https://regional.kompas.com/read/2016/02/03/01103591/Warga.Tiga.Kecamata n.di.Bantul.Tolak.Eks.Gafatar.

Darmawan, Budi. "Ini Gafatar cara merekrut anggotanya", 14 Januari 2016. http://palembang.tribunnews.com/2016/01/14/ini-cara-gafatar-merekrutanggotanya

Fachrudin, A. A. "Gafatar dalam Narasi: Melampaui Isu Agama” telah dipublikasikan di http://crcs.ugm.ac.id/ pada tanggal 24 Oktober 2016

Fira."Pengusiran 1.000 Eks Anggota Gafatar Merupakan Pelanggaran". 21 Januari 2016. http://www.obsessionnews.com/daerah/pengusiran-1-000-eks-anggotagafatar-merupakan-pelanggaran/.

Firdaus, Fahmi “Gelar Rakernas, Gafatar siap wujudkan kedaulatan pangan”. 27 Februari 2015. https://news.okezone.com/read/2015/02/27/337/1111695/gelarrakernas-gafatar-siap-wujudkan-kedaulatan-pangan.

Kusuma,Wijaya "Gafatar sudah bubar sejak 2015”. 12 Januari 2016. https://regional.kompas.com/read/2016/01/12/14323651/. Gafatar.Sudah.Bubar.sejak.2015

Puspitasari, M. A dkk. “Mereka bingung jika pulang ke kampung halaman” Tempo, edisi Januari 2016

Ravishop, "GAFATAR: Persoalan pangan adalah persoalan hidup dan mati”. 9 Maret 2017. http//sayangi.com/berita/2017/03/09/GAFATAR-Persoalan-Panganadalah-persoalan-Hidup-dan-Mati/ 


$$
\text { “Apa itu Gerakan Gajar Utama (GAFATAR)?”. }
$$

Gafatarian.blogspot.co.id. 11 Januari 2016.

Sabandar, Switzi. " untuk program pangan, Gafatar punya 5 ribu Ha di Kalimantan". 20 Januari 2016. https://nasional.tempo.co/read/737775/untuk-progampangan-gafatar-punya-5-ribu-ha-di-kalimantan

Trianita, Linda. Dkk. "Kepala Polri sebut Gafatar ingin dirikan negara sendiri” Tempo, edisi 26 Januari 2016

Puspitasari, M. A dkk. "Mereka bingung jika pulang ke kampung halaman" Tempo,edisi 25 Januari 2016 